\title{
AN INTEGRATED APPROACH TO THE ENTERPRISES' BUSINESS EFFICIENCY ASSESSMENT
}

\author{
Ivan F. Balaniuk ${ }^{1}$, Diana I. Shelenko², Mykola V. Biloshkurskyi ${ }^{3}$, Inna M. Povorozniuk ${ }^{4}$, \\ Lesia A. Slatvinska ${ }^{5}$
}

\author{
${ }^{1}$ Professor, Doctor of Economics, Vasyl Stefanyk Precarpathian National University, \\ 57 Shevchenko str., Ivano-Frankivsk, 76010, Ukraine.E-mail: ivan.balaniuk@pnu.edu.ua \\ ${ }^{2}$ Associate Professor, Doctor of Economics, Vasyl Stefanyk Precarpathian National University, \\ 57 Shevchenko str., Ivano-Frankivsk, 76010,Ukraine.E-mail: diana.shelenko@pnu.edu.ua \\ ${ }^{3}$ Associate Professor, PhD of Economics, Pavlo Tychyna Uman State Pedagogical University, \\ 2 Sadova str., Uman, Cherkasy region, 20300, Ukraine. E-mail: biloshkurskyi.m@udpu.edu.ua \\ ${ }^{4}$ Associate Professor, PhD of Economics, Pavlo Tychyna Uman State Pedagogical University, 2 Sadova str., Uman, \\ Cherkasy region, 20300,Ukraine.E-mail: povorozniuk.i@udpu.edu.ua \\ ${ }^{5}$ PhD of Economics, Pavlo Tychyna Uman State Pedagogical University, 2 Sadova str., Uman, Cherkasy region, 20300, \\ Ukraine.E-mail: slatvinska.l@udpu.edu.ua
}

Received 1110202010 11; Accepted 18122020

\begin{abstract}
In the enterprise management system, the assessment of business efficiency occupies a leading place, since the adoption of strategically significant management decisions depends on its results. Since business efficiency is a multidimensional phenomenon, its assessment involves the use of many indicators, which complicates management. The integrated approach, as a modern progressive methodological apparatus, allows systematize indicators into subindexes and to obtain a single integrated indicator of the enterprises' business efficiency. That is why the purpose of the study is to introduce an integrated approach to the system of enterprises' business efficiency assessment as an important methodological tool. For this purpose, such methods as normalization of analytical data, averages, correlation analysis, aggregation, coefficient analysis, graphical and tabular expression of analytical data were used. In the course of the research, 12 individual indicators were normalized, on the basis of which 3 subindexes of business efficiency of agricultural enterprises were calculated: by results of activities, by resource efficiency, and by the scale of production. The Agricultural Enterprises' Business Efficiency Index was formed as the sum of the products of subindexes with weights calculated by the criterion of the density of the relationship between them. It is determined that the main factors influencing the efficiency of agricultural enterprises in Ukraine are sales of agricultural products, staff costs, and produced agricultural products (goods, services).
\end{abstract}

Keywords: agricultural enterprises, index, indicator, methodological support, production, subindex.

JEL Codes: C32, D61, Q13.

\section{Introduction}

The business efficiency of the enterprise is the most important sign of its viability. First of all, business efficiency is the ability of the enterprise to generate income and profit even under the most unfavourable external and internal conditions. In this case, the external conditions are those that do not directly depend on the actions of the enterprise, in particular market demand, conditions for doing business, the general state of society, the state of the financial and credit system, and so on. Internal conditions are those that are formed as a result of the enterprise, in particular, added value production, resource potential, production capacity, innovation, and so on. In this regard, the business efficiency assessment of enterprise is a multifaceted component of management, which includes a significant number of absolute or monetary indicators and ratios, their dynamics, and criteria.

Copyright (C) 2020. Published by Vytautas Magnus University. This is an open access article distributed under the terms of the Creative Commons Attribution Non-Commercial 4.0 (CC BY-NC 4.0) license, which permits unrestricted use, distribution, and reproduction in any medium provided the original author and source are credited. The material cannot be used for commercial purposes. 
The problem of business efficiency assessment is complex due to its multi-vector nature. Researchers must analyse the results of activities (income, production, profit, profitability), the efficiency of human and physical capital, the scale of production (output and costs, investment), etc. Therefore, there is a need for methods with which it would be possible to statistically process a considerable number of indicators reflecting various aspects of business efficiency. We offer the introduction of an integrated approach to assessing business efficiency. And today it is the most progressive method.

Analysing scientific sources on the problem of a complex assessment of business efficiency, it should be noted that recent research was conducted in several directions. Scientists of the first direction, for example, Bogdan and Sava (2018), Dragan, Berher, and Pustovit (2018), Levkina and Petrenko (2019), Prdic, Kuzman and Damjanovic (2019), in their works focus on the impact of the external environment on the efficiency of the enterprise, primarily the market situation and adaptation of marketing management. Scientists of the second direction of research of business efficiency are engaged in methodological support of its assessment, in particular: a comparative analysis of modern assessment methods (Cabinova et al., 2018); the introduction of non-financial indicators into the system for analyzing the business efficiency of small and medium-sized enterprises (Dobrovic, Lambovska, Gallo, Timkova, 2018); the use of matric methods in assessing and forecasting the business efficiency of small and medium-sized enterprises to form the prerequisites for the formation of their international competitiveness (Landika, Sredojevic, Jakupovic, 2018); the introduction of integral assessment into the management system of the sustainable development (Sokil, Zhuk, Laszlo, 2018). The third approach is to study the impact of automation on business efficiency and the introduction of IT in the system of accounting, analysis, and auditing, it is revealed in the works of D. Kim and S. Choi (2018), Vallisova, Cerna and Hinke (2018), Rahmatullin and Guzelbaeva, (2019), L.-H. Ma, J.-C. Hsieh and Y.-H. Chiu (2020). The fourth approach is related to the applied aspects of business efficiency assessment, which are disclosed in the works of Mann and Bilyk (2017), Li, Liu, Zhu and Zhang (2018), Prokopenko and Kornatowski (2018), Tambunan (2019), GutierrezFernandez and Fernandez-Torres (2020). Despite the significant amount of scientific research on business efficiency assessment, the problem of implementing an integrated approach is insufficiently studied. The methodological potential of the integrated approach is powerful and allows us to combine many individual indicators in a single integrated indicator (index).

The main purpose of the article is to introduce an integrated approach to the business efficiency assessment of enterprises.

\section{Research methods}

To investigation the business efficiency of enterprises, it is advisable to use methodological support for integrated assessment. The integrated approach will allow not only to comprehensively assess the dynamics of business efficiency of enterprises in Ukraine but also to conduct a qualitative comparative analysis of its components. The results of the integrated assessment will identify the main problems of business efficiency and develop ways to solve them. The main source of calculations will be public data of official statistics, posted on the official website of the State Statistics Service of Ukraine (2020). The article will introduce an integrated approach to assessing the business efficiency of agricultural enterprises in Ukraine, since the agricultural sector of Ukraine is of strategic importance and export orientation, and its contribution to GDP is growing every year, ahead of other sectors of the economy.

To implement the integrated approach, it is necessary to make appropriate calculations of both individual indicators (set empirically) and subindexes (include several individual indicators), formed by main directions, as well as a complex index (integrated indicator) of business efficiency of agricultural enterprises of Ukraine, including all subindexes. It is also important to interpret the levels of business efficiency to determine the critical values of the integrated indicator. 
It should be noted that the integrated assessment initially involves the normalization of individual indicators by the formulas:

$$
Z_{i j \uparrow}=\frac{X_{i j}-X_{\min }}{X_{\max }-X_{\min }}
$$

where $X_{i j}$ is the $i$-th value of the $j$-th individual indicator, which is normalized;

$X_{\min }$ and $X_{\max }$ are respectively, the minimum and maximum of the array of $i$-th values of the $j$-th individual indicator;

$Z_{i j \uparrow}$ is the normalized value of $X_{i j}$, if an individual indicator is a stimulant (its growth indicates an increase in the level of business efficiency of the agricultural enterprise);

$$
Z_{i j \downarrow}=\frac{X_{\max }-X_{i j}}{X_{\max }-X_{\min }}
$$

where $Z_{i j \downarrow}$ is the normalized value of $X_{i j}$, if an individual indicator is a destimulator (its growth indicates an increase in the level of business efficiency of the agricultural enterprise).

The set of individual indicators of business efficiency of agricultural enterprises, determined empirically, in the integrated assessment should be divided into several common features (components), on the basis of which subindexes are formed, usually at least two. Subindex is the weighted average of normalized indicators, which we propose to calculate by the arithmetic mean formula:

$$
\hat{S}_{C_{i}}=\frac{1}{m} \sum_{j=1}^{m} Z_{1}+Z_{2}+\cdots+Z_{j},
$$

where $\hat{S}_{C_{i}}$ is the subindex of the $i$-th component of the business efficiency level of agricultural enterprises, $i=\overline{1 ; n}$;

$Z_{1}, Z_{2}, \ldots, Z_{j}$ are normalized individual indicators of the business efficiency component of agricultural enterprises, calculated by formulas (1)-(2), $j=\overline{1 ; m}$.

The integrated approach involves the construction of an index (integrated indicator) of the business efficiency of agricultural enterprises, which is the weighted average of the subindexes calculated by the formula (3). We propose to calculate the index (integrated indicator) of business efficiency of agricultural enterprises $\left(I_{S D_{A E}}\right)$ according to the formula of arithmetic weighted average:

$$
I_{S D_{A E}}=w_{1} \hat{S}_{C_{1}}+w_{2} \hat{S}_{C_{2}}+\cdots+w_{i} \hat{S}_{C_{i}},
$$

where $w_{1}, w_{2}, \ldots, w_{i}$ are weighting coefficients of the $i$-th subindex of the agricultural enterprises business efficiency, with

$$
\sum_{i=1}^{n} w_{i}=1
$$

Thus, the integrated approach is an important methodological apparatus for the business efficiency assessment of agricultural enterprises. The most difficult to calculate the weights of subindexes. To do this, we use the methodological approach proposed in (Biloshkurska et al., 2019; Ponomarenko et al., 2019). The weighting factors of the business efficiency subindexes of agricultural enterprises are based on the criteria of the density of the relationship between them. Dominant or the most important among subindex is the sum of modules of numerical values of the pairwise correlation coefficients between which and the rest of the subindexes is the largest. It should be noted that the density of the stochastic relationship between statistics is expressed by the value of the pairwise 
correlation coefficient, not the direction of influence (inverse or direct), so the modules of numerical values of pairwise correlation coefficients between subindexes are used to calculate weights. Thus, for the first business efficiency subindex of agricultural enterprises $\left(\hat{S}_{C_{1}}\right)$, the formula takes the form:

$$
w_{1}=\sum_{i=1}^{n}\left|r_{x_{i} x_{1}}\right| / \sum_{j=1}^{m}\left|r_{x_{i} x_{j}}\right| \text {, }
$$
subindexes;

where $r_{x_{i} x_{1}}$ is the pairwise correlation coefficient between subindex $\hat{S}_{C_{1}}$ and other $i$-th

for subindex $\hat{S}_{C_{2}}$ :

$$
w_{2}=\sum_{i=1}^{n}\left|r_{x_{i} x_{2}}\right| / \sum_{j=1}^{m}\left|r_{x_{i} x_{j}}\right| .
$$

for subindex $\hat{S}_{C_{3}}$ :

$$
w_{3}=\sum_{i=1}^{n}\left|r_{x_{i} x_{3}}\right| / \sum_{j=1}^{m}\left|r_{x_{i} x_{j}}\right| \text {. }
$$

\section{Research results and discussion}

To improve the methodological support of the integrated approach as a tool for business efficiency assessment of agricultural enterprises, we will first identify the individual indicators and group them by three components: results of activities, resource efficiency, and scale of production (Table 1).

\begin{tabular}{|c|c|c|}
\hline Indicator & Method of calculation (units of measurement) & $\begin{array}{l}\text { Nature of } \\
\text { influence* }\end{array}$ \\
\hline \multicolumn{3}{|c|}{ 1. Indicators for business efficiency assessment of agricultural enterprises by the results of activities } \\
\hline $\begin{array}{l}\text { 1.1. Sale of agricultural products } \\
\text { (per } 1 \text { enterprise) }\end{array}$ & $\begin{array}{l}\text { the ratio of sales of agricultural products to the number of } \\
\text { agricultural enterprises (UAH) }\end{array}$ & stimulant \\
\hline $\begin{array}{l}\text { 1.2. Added value of agricultural } \\
\text { production (per } 1 \text { enterprise) }\end{array}$ & $\begin{array}{l}\text { the ratio of the value added of agricultural production to the number } \\
\text { of agricultural enterprises (UAH) }\end{array}$ & stimulant \\
\hline 1.3. Net profit (per 1 enterprise) & $\begin{array}{l}\text { the ratio of net profit to the number of agricultural enterprises } \\
\text { (UAH) }\end{array}$ & stimulant \\
\hline $\begin{array}{l}\text { 1.4. Profitability of operating } \\
\text { activity (per } 1 \text { enterprise) }\end{array}$ & $\begin{array}{l}\text { the ratio of the result from operating activities to operating expenses } \\
(\%)\end{array}$ & stimulant \\
\hline \multicolumn{3}{|c|}{ 2. Indicators for business efficiency assessment of agricultural enterprises by resource efficiency } \\
\hline $\begin{array}{l}\text { 2.1. Labour productivity (per } 1 \\
\text { enterprise) }\end{array}$ & $\begin{array}{l}\text { the ratio of the volume of agricultural products (goods, services) to } \\
\text { the number of employees in agricultural enterprises (UAH / person) }\end{array}$ & stimulant \\
\hline $\begin{array}{l}\text { 2.2. Capital productivity (per } 1 \\
\text { enterprise) }\end{array}$ & $\begin{array}{l}\text { the ratio of the volume of agricultural products (goods, services) to } \\
\text { the value of non-current assets }\end{array}$ & stimulant \\
\hline $\begin{array}{l}\text { 2.3. Capital-labour ratio (per } 1 \\
\text { enterprise) }\end{array}$ & $\begin{array}{l}\text { the ratio of the value of non-current assets to the number of } \\
\text { employees in agricultural enterprises (UAH / person) }\end{array}$ & stimulant \\
\hline $\begin{array}{l}\text { 2.4. Material consumption of } \\
\text { products (per } 1 \text { enterprise) }\end{array}$ & $\begin{array}{l}\text { the ratio of material costs and costs of services used in production to } \\
\text { the volume of agricultural products (goods, services) }\end{array}$ & destimulator \\
\hline \multicolumn{3}{|c|}{ 3. Indicators for business efficiency assessment of agricultural enterprises by the scale of production } \\
\hline $\begin{array}{l}\text { 3.1. Produced agricultural } \\
\text { products (per } 1 \text { enterprise) }\end{array}$ & $\begin{array}{l}\text { the ratio of produced agricultural products (goods, services) to the } \\
\text { number of agricultural enterprises (UAH) }\end{array}$ & stimulant \\
\hline $\begin{array}{l}\text { 3.2. Costs of agricultural } \\
\text { production (per } 1 \text { enterprise) }\end{array}$ & $\begin{array}{l}\text { the ratio of costs of agricultural production to the number of } \\
\text { agricultural enterprises (UAH) }\end{array}$ & stimulant \\
\hline 3.3. Staff costs (per 1 enterprise) & ratio of staff costs to the number of agricultural enterprises (UAH) & stimulant \\
\hline $\begin{array}{l}\text { 3.4. Capital investments (per } 1 \\
\text { enterprise) }\end{array}$ & $\begin{array}{l}\text { the ratio of capital investment to the number of agricultural } \\
\text { enterprises (UAH) }\end{array}$ & stimulant \\
\hline
\end{tabular}

Table 1. Identification and grouping of individual indicators for business efficiency assessment of agricultural enterprises 
To ensure the objectivity of the assessment and to eliminate the impact of inflation on the business efficiency of agricultural enterprises, will first be indexed all monetary inputs used to calculate individual indicators (Table 1), taking into account the average annual inflation rate. At the same time, the most universal macroeconomic level of inflation will be the basic GDP deflator indices. Using the data shown in Table 1, we will calculate and discount single indicators on the basic indices of the GDP deflator (the base year 2012), which will be included in the agricultural enterprises' business efficiency index, within its components for 2012-2018 (Table 2). That is, the business efficiency assessment of agricultural enterprises is based on real indicators calculated in 2012 prices, and its objectivity is ensured by eliminating the impact of inflation.

Table 2. Individual indicators of business efficiency of agricultural enterprises of Ukraine

\begin{tabular}{|c|c|c|c|c|c|c|c|c|c|}
\hline \multirow{2}{*}{ Indicator } & \multicolumn{7}{|c|}{ Indicator value by years: } & \multicolumn{2}{|c|}{ Extreme values } \\
\hline & 2012 & 2013 & 2014 & 2015 & 2016 & 2017 & 2018 & $\min$ & $\max$ \\
\hline $\begin{array}{l}\text { 1.1. Sale of agricultural } \\
\text { products (per } 1 \text { enterprise), } \\
\text { thousand UAH }\end{array}$ & $3,159.4$ & $2,869.6$ & $3,561.3$ & $4,274.3$ & $4,224.3$ & $3,496.9$ & $3,474.9$ & $2,869.6$ & $4,274.3$ \\
\hline $\begin{array}{l}\text { 1.2. Added value of } \\
\text { agricultural production } \\
\text { (per } 1 \text { enterprise), } \\
\text { thousand UAH }\end{array}$ & $1,445.7$ & $1,240.8$ & $2,088.6$ & $2,169.2$ & $1,956.3$ & $1,504.2$ & $1,336.3$ & $1,240.8$ & $2,169.2$ \\
\hline $\begin{array}{l}\text { 1.3. Net profit (per } 1 \\
\text { enterprise), thousand UAH }\end{array}$ & 520.5 & 266.9 & 357.6 & $1,213.3$ & 948.3 & 529.9 & 469.9 & 266.9 & $1,213.3$ \\
\hline $\begin{array}{l}\text { 1.4. Profitability of } \\
\text { operating activity (per } 1 \\
\text { enterprise), } \%\end{array}$ & 21.7 & 11.3 & 20.6 & 41.7 & 32.4 & 22.4 & 18.3 & 11.3 & 41.7 \\
\hline $\begin{array}{l}\text { 2.1. Labour productivity } \\
\text { (per } 1 \text { enterprise), } \\
\text { thousand UAH / person }\end{array}$ & 233.2 & 260.9 & 361.0 & 396.2 & 375.3 & 353.2 & 368.0 & 233.2 & 396.2 \\
\hline $\begin{array}{l}\text { 2.2. Capital productivity } \\
\text { (per } 1 \text { enterprise) }\end{array}$ & 1.726 & 1.625 & 2.284 & 2.390 & 2.127 & 1.876 & 1.825 & 1.625 & 2.390 \\
\hline $\begin{array}{l}\text { 2.3. Capital-labour ratio } \\
\text { (per } 1 \text { enterprise), } \\
\text { thousand UAH / person }\end{array}$ & 135.1 & 160.6 & 158.1 & 165.8 & 176.4 & 188.3 & 201.7 & 135.1 & 201.7 \\
\hline $\begin{array}{l}\text { 2.4. Material consumption } \\
\text { of products (per } 1 \\
\text { enterprise) }\end{array}$ & 0.582 & 0.641 & 0.545 & 0.552 & 0.576 & 0.610 & 0.640 & 0.545 & 0.641 \\
\hline $\begin{array}{l}\text { 3.1. Produced agricultural } \\
\text { products (per } 1 \text { enterprise), } \\
\text { thousand UAH }\end{array}$ & $3,414.5$ & $3,413.2$ & $4,676.6$ & $4,826.4$ & $4,866.4$ & $3,933.9$ & $3,976.9$ & $3,413.2$ & $4,866.4$ \\
\hline $\begin{array}{l}\text { 3.2. Costs of agricultural } \\
\text { production (per } 1 \\
\text { enterprise), thousand UAH }\end{array}$ & $2,609.7$ & $2,808.0$ & $3,161.5$ & $3,244.0$ & $3,417.4$ & $2,993.1$ & $3,186.6$ & $2,609.7$ & $3,417.4$ \\
\hline $\begin{array}{l}\text { 3.3. Staff costs (per } 1 \\
\text { enterprise), thousand UAH }\end{array}$ & 433.3 & 411.9 & 392.2 & 336.2 & 345.3 & 337.1 & 364.4 & 336.2 & 433.3 \\
\hline $\begin{array}{l}\text { 3.4. Capital investments } \\
\text { (per } 1 \text { enterprise), } \\
\text { thousand UAH }\end{array}$ & 373.2 & 336.9 & 309.3 & 351.5 & 526.6 & 493.2 & 440.6 & 309.3 & 526.6 \\
\hline
\end{tabular}

Source: formed and calculated according to the official websites of the State Statistics Service of Ukraine (2020) and National Bank of Ukraine (2020).

The data presented in Table 2 show a general decline in all individual indicators of business efficiency of agricultural enterprises by the results of activities, except $+10 \%$ for sales of agricultural products (per 1 enterprise) during 2012-2018. In particular, the added value of agricultural production decreased by $7.5 \%$ with a decrease in net profit by $9.7 \%$ and the profitability of operating activities by $3.5 \%$. 
Among the individual indicators of business efficiency of agricultural enterprises in terms of resource efficiency, the average annual labour productivity of 1 agricultural enterprise increased the most $(+57 \%)$, and the least $(+6 \%)$ capital return of 1 enterprise. This may indicate a faster growth of the role of human capital (the number of employees decreased by $22 \%$ ) compared to physical (the value of non-current assets increased by 17\%), which also indicates an increase in labour capital by $49 \%$ with increasing agricultural output (goods, services) by $23 \%$ during 2012-2018. At the same time, the increase in the average annual material consumption of the products of 1 enterprise was $+10 \%$.

Comparative dynamics of individual indicators of business efficiency of agricultural enterprises by the scale of production indicates the priority of physical capital over human capital for the owner, as in 2012-2018 there was an increase in average annual capital investment (per 1 enterprise) by $18 \%$ while reducing staff costs by $16 \%$. The prevailing dynamics of average annual production costs $(+22 \%)$ over the output $(+16.5 \%)$ of agricultural products of 1 enterprise is the reason for the reduction in profitability.

Thus, to business efficiency assessment of agricultural enterprises, the formalization of its main components was carried out, as a result of which the main trends in 3 key areas were identified - results of activities, resource efficiency, and scale of production.

To calculate the business efficiency subindexes of agricultural enterprises, we will normalize the individual indicators listed in Table 2 using formulas (1)-(3). Based on the results of the calculations, we will form Table 3.

Table 3. Normalized individual indicators and business efficiency subindexes of agricultural enterprises of Ukraine

\begin{tabular}{|c|c|c|c|c|c|c|c|}
\hline \multirow{2}{*}{ Indicator } & \multicolumn{7}{|c|}{ Indicator value by years: } \\
\hline & 2012 & 2013 & 2014 & 2015 & 2016 & 2017 & 2018 \\
\hline $\begin{array}{l}\text { Normalized sale of agricultural products (per } 1 \\
\text { enterprise) }\left(Z_{11 \uparrow} \uparrow ;\right.\end{array}$ & 0.206 & 0 & 0.492 & 1 & 0.964 & 0.447 & 0.431 \\
\hline $\begin{array}{l}\text { Normalized added value of agricultural production (per } 1 \\
\text { enterprise) }\left(Z_{12 \uparrow}\right) ;\end{array}$ & 0.221 & 0 & 0.913 & 1 & 0.771 & 0.284 & 0.103 \\
\hline Normalized net profit (per 1 enterprise) $\left(Z_{13 \uparrow} \uparrow\right.$ & 0.268 & 0 & 0.096 & 1 & 0.720 & 0.278 & 0.214 \\
\hline $\begin{array}{l}\text { Normalized profitability of operating activity (per } 1 \\
\text { enterprise) }\left(Z_{14 \uparrow}\right) \text {. }\end{array}$ & 0.344 & 0 & 0.306 & 1 & 0.696 & 0.365 & 0.230 \\
\hline $\begin{array}{l}\text { Business efficiency subindex of agricultural enterprises } \\
\text { by the results of activities }\left(\widehat{S}_{B E_{B A}}\right)\end{array}$ & 0.260 & 0 & 0.452 & 1 & 0.788 & 0.343 & 0.245 \\
\hline Normalized labour productivity (per 1 enterprise) $\left(Z_{21} \uparrow\right)$ & 0 & 0.170 & 0.784 & 1 & 0.872 & 0.736 & 0.827 \\
\hline Normalized capital productivity (per 1 enterprise) $\left(Z_{22} \uparrow\right)$; & 0.132 & 0 & 0.861 & 1 & 0.657 & 0.328 & 0.261 \\
\hline Normalized capital-labour ratio (per 1 enterprise) $\left(Z_{23} \uparrow\right)$; & 0 & 0.382 & 0.345 & 0.460 & 0.621 & 0.799 & 1 \\
\hline $\begin{array}{l}\text { Normalized material consumption of products (per } 1 \\
\text { enterprise) }\left(Z_{24} \downarrow\right) \text {. }\end{array}$ & 0.618 & 0 & 1 & 0.921 & 0.680 & 0.329 & 0.014 \\
\hline $\begin{array}{l}\text { Business efficiency subindex of agricultural enterprises } \\
\text { by resource efficiency }\left(\widehat{S}_{B E_{R E}}\right)\end{array}$ & 0.188 & 0.138 & 0.747 & 0.845 & 0.707 & 0.548 & 0.526 \\
\hline $\begin{array}{l}\text { Normalized produced agricultural products (per } 1 \\
\text { enterprise) }\left(Z_{31} \uparrow\right)\end{array}$ & 0.001 & 0 & 0.869 & 0.972 & 1 & 0.358 & 0.388 \\
\hline $\begin{array}{l}\text { Normalized costs of agricultural production (per } 1 \\
\text { enterprise) }\left(Z_{32} \uparrow\right)\end{array}$ & 0 & 0.245 & 0.683 & 0.785 & 1 & 0.475 & 0.714 \\
\hline Normalized staff costs (per 1 enterprise) $\left(Z_{33 \uparrow}\right) ;$ & 1 & 0.780 & 0.576 & 0 & 0.093 & 0.009 & 0.290 \\
\hline Normalized capital investments (per 1 enterprise) $\left(Z_{34} \uparrow\right)$. & 0.294 & 0.127 & 0 & 0.194 & 1 & 0.846 & 0.604 \\
\hline $\begin{array}{l}\text { Business efficiency subindex of agricultural enterprises } \\
\text { by the scale of production }\left(\widehat{S}_{B E_{S P}}\right)\end{array}$ & 0.324 & 0.288 & 0.532 & 0.488 & 0.773 & 0.422 & 0.499 \\
\hline
\end{tabular}
Source: formed and calculated according to the data given in Table 1 and formulas (1)-(3).

The data in Table 2 show the following dynamics of business efficiency subindexes of agricultural enterprises during 2012-2018: the business efficiency subindex of agricultural enterprises by the results of activities decreased by $6 \%$, reaching the lowest level in 2013 and the 
highest in 2015; the business efficiency subindex of agricultural enterprises by resource efficiency increased by $180 \%$, reaching the lowest level in 2013 and the highest in 2015; the business efficiency subindex of agricultural enterprises by the scale of production increased by $54 \%$, reaching the lowest level in 2013 and the highest in 2016.

To determine the weight coefficients of business efficiency subindexes of agricultural enterprises use formulas (4)-(8). To do this, we first construct a correlation matrix based on the calculated values of subindexes (Table 4).

Table 4. Correlation matrix of the business efficiency subindexes of agricultural enterprises of Ukraine

\begin{tabular}{|c|c|c|c|}
\hline & $\widehat{\boldsymbol{S}}_{\boldsymbol{S D _ { R A }}}$ & $\widehat{\boldsymbol{S}}_{\boldsymbol{S D _ { R E }}}$ & $\widehat{\boldsymbol{S}}_{\boldsymbol{S D _ { S P }}}$ \\
\hline$\hat{S}_{S D_{R A}}$ & 1 & & \\
\hline$\hat{S}_{S D_{R E}}$ & 0.8404 & 1 & 1 \\
\hline$\hat{S}_{S D_{S P}}$ & 0.6720 & 0.7362 & \\
\hline
\end{tabular}

Source: calculated by the authors

We calculate the weighting coefficients of the business efficiency subindexes of agricultural enterprises of Ukraine, using formulas (6)-(8), according to the data given in table 4:

$$
\begin{gathered}
w_{1}=\sum_{i=1}^{n}\left|r_{x_{i} x_{1}}\right| / \sum_{j=1}^{m}\left|r_{x_{i} x_{j}}\right|=\frac{1.512}{4.497}=0.336, \\
w_{2}=\sum_{i=1}^{n}\left|r_{x_{i} x_{2}}\right| / \sum_{j=1}^{m}\left|r_{x_{i} x_{j}}\right|=\frac{1.577}{4.497}=0.351, \\
w_{3}=\sum_{i=1}^{n}\left|r_{x_{i} x_{3}}\right| / \sum_{j=1}^{m}\left|r_{x_{i} x_{j}}\right|=\frac{1.408}{4.497}=0.313 .
\end{gathered}
$$

Based on formulas (9)-(11) we will form the final equation of the Agricultural Enterprises' Business Efficiency Index for Ukraine, where the Business Efficiency Subindex of Agricultural Enterprises by Resource Efficiency has the greatest weight:

$$
I_{S D_{A E}}=0.336 \widehat{S}_{B E_{R A}}+0.351 \widehat{S}_{B E_{R E}}+0.313 \widehat{S}_{B E_{S P}} .
$$

The results of calculations of the Agricultural Enterprises' Business Efficiency Index for Ukraine by formula (12) are illustrated in Figure 1.

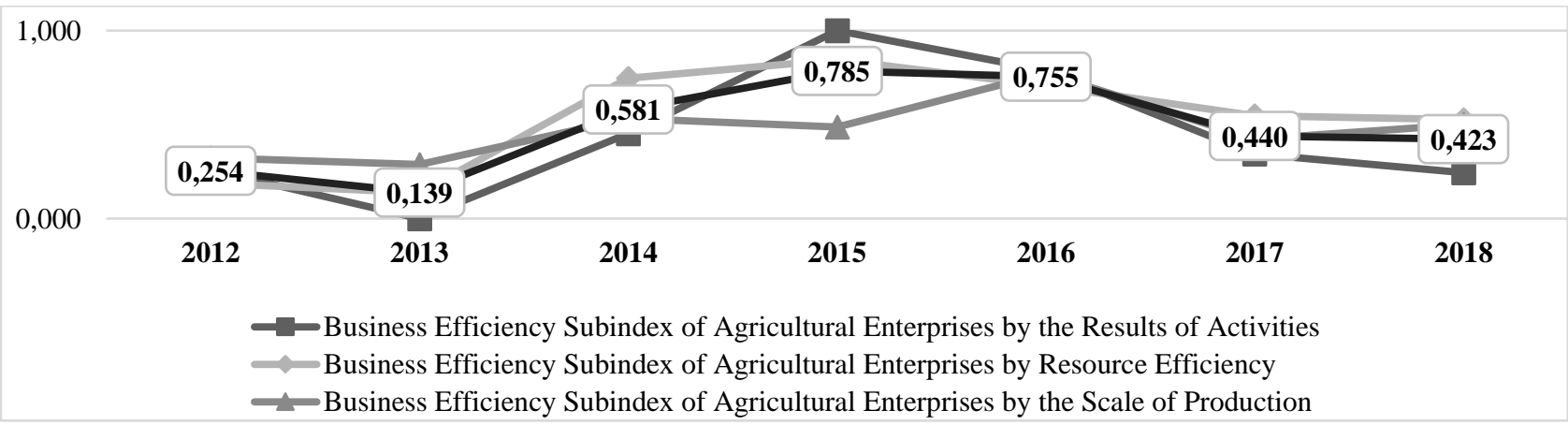

Figure 1. Dynamics of the Agricultural Enterprises' Business Efficiency Index for Ukraine and its components in 2012-2018

Source: calculated by the authors according to the data given in Table 3 and formula (12). 
Interpretation of the Agricultural Enterprises' Business Efficiency Index for Ukraine will be carried out on the basis of critical values and the corresponding levels: $I_{B E_{A E}} \in[0 ; 0.25)$ is the level of inefficiency business; $I_{\boldsymbol{B E}_{A E}} \in[0.25 ; 0.5)$ is the low level of business efficiency; $I_{B E_{A E}} \in[0.5 ; 0.75)$ is the sufficient level of business efficiency; $I_{B E_{A E}} \in[0.75 ; 1]$ is the high level of business efficiency. It is also worth noting that the results obtained are representative only for the 2012-2018 range. The introduction of new data for subsequent or previous periods will lead to the need for new calculations, which may differ from those shown in Figure 1.

The data in Figure 1 show that in 2012 the level of agricultural enterprises' business efficiency for Ukraine was low, and in 2013 it decreased to the level of inefficiency business. However, already in 2014, the business efficiency of agricultural enterprises in Ukraine became average, and in 20152016 it was high. The Agricultural Enterprises' Business Efficiency Index last 2 years of analysis consistently low. The identified trends developed primarily under the influence of agricultural enterprises' economic activity dynamics, as evidenced by the values of paired coefficients of determination ( $\mathrm{R}$ squared) between the values of the business efficiency index and the following results of agricultural enterprises of Ukraine: sales of agricultural products, value added of agricultural products, net profit, produced agricultural products (goods, services), costs of agricultural products, staff costs, capital investments, material costs and costs of services used in production (Figure 2).

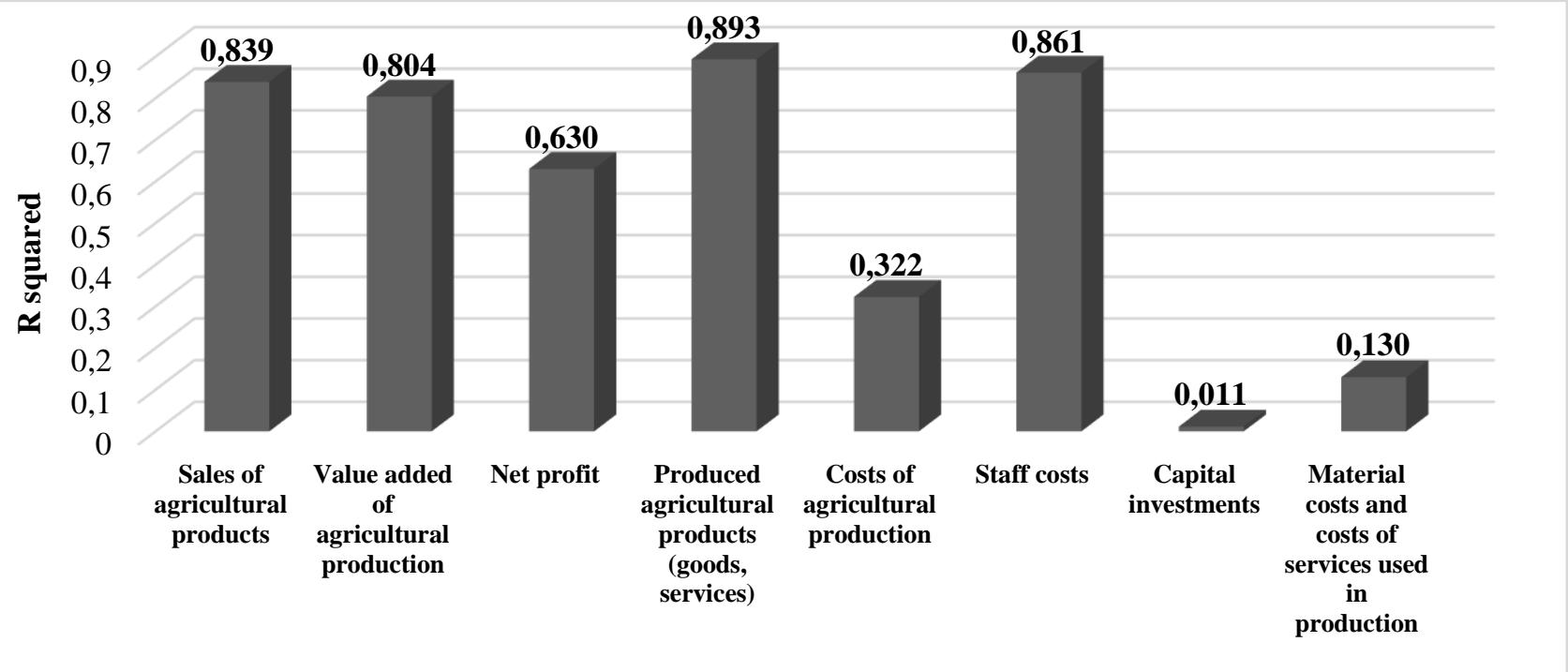

Figure 2. Ranking of factors influencing of the business efficiency index of agricultural enterprises by the coefficient of determination $\left(\mathbf{R}^{2}\right)$

Source: calculated by the authors

Data in Figure 2 reveal that 3 indicators have the greatest influence on agricultural enterprises' business efficiency. They are:

1) produced agricultural products (goods, services) as a domestic production factor;

2) staff costs as a motivational factor;

3) sales of agricultural products as a demand factor.

This conclusion can be made on the basis of ranking the $\mathrm{R}$ squared values. These factors should be a priority for managers of agricultural enterprises in business planning. Of course, the proposed methodological support of integrated assessment will be the main tool for assessing agricultural enterprises' business efficiency. 


\section{Conclusions}

Thus, in the course of the study, the main goal of the successful implementation of the integrated approach to the assessment of agricultural enterprises' business efficiency was realized. This allowed to obtain the following scientific results:

Firstly, the necessity of normalization and equivalence of normalized 12 individual indicators, grouped in 3 subindexes, calculated with the help of arithmetic mean, is substantiated: 1) the business efficiency subindex of agricultural enterprises by the results of activities, 2) the business efficiency subindex of agricultural enterprises by resource efficiency, 3) the business efficiency subindex of agricultural enterprises by the scale of production.

Secondly, the Agricultural Enterprises' Business Efficiency Index is proposed as an arithmetic weighted average of 3 business efficiency subindexes of agricultural enterprises, the weighting factors of which are calculated taking into account the criterion of the density of the relationship between them.

Thirdly, it is proved that the greatest influence on the business efficiency of agricultural enterprises of Ukraine during 2012-2018 was exerted by indicators as sales of agricultural products, staff costs, and produced agricultural products (goods, services).

Fourthly, the developed methodological support for the integrated assessment of agricultural enterprises' business efficiency will be used in further research of the authors for analysis at the intersectoral and interstate levels.

\section{References}

Biloshkurska, N., Harnyk, O., Biloshkurskyi, M., Liannoi, M., Kudrina, O., Omelyanenko, V. (2019). Methodological bases of innovation development priorities integrated assessment // International Journal of Civil Engineering and Technology. Vol. 10. No. 1: 1231-1240.

Bogdan, M., Sava, A. (2018). Supply chain finance, a solution to improve business efficiency. ACTA Technica Napocensis - Series: Applied Mathematics Mechanics and Engineering. Vol. 61. No. 4: 625-630. - https://atnamam.utcluj.ro/index.php/Acta/article/view/1110 [2020 10 01].

Cabinova, V., Onuferova, E., Gallo, P. Jr., Gallo, P., Gallo, J. (2018). A comparative analysis of modern performance methods in economic practice // Montenegrin Journal of Economics. Vol. 14. No. 4: 85-96. https://doi.org/10.14254/1800-5845/2018.14-4.6.

Dobrovic, J., Lambovska, M., Gallo, P., Timkova, V. (2018). Non-financial indicators and their importance in small and medium-sized enterprises // Journal of Competitiveness. Vol. 10. No. 2: 41-55. https://doi.org/10.7441/joc.2018.02.03.

Dragan, O., Berher, A., Pustovit, J. (2018). Estimation of marketing price policy efficiency of the enterprise of meat-processing industry // Management Theory and Studies for Rural Business and Infrastructure Development. Vol. 40. No. 2: 175-186. - https://doi.org/10.15544/mts.2018.17.

Gutierrez-Fernandez, M., Fernandez-Torres, Y. (2020). Does gender diversity influence business efficiency? An analysis from the social perspective of CSR // Sustainability. Vol. 12. No. 9. - https://doi.org/10.3390/su12093865.

Kim, D. G., Choi, S, O. (2018). Impact of construction IT technology convergence innovation on business performance // Sustainability. Vol. 10. No. 11. - https://doi.org/10.3390/su10113972.

Landika, M., Sredojevic, V., Jakupovic, S. (2018). Matric aspects of predictions of business efficiency of small and medium enterprises as precondition of international competitiveness // Casopis za ekonomiju i trzisne komunikacije. Vol. 8. No. 1: 108-117. - https://doi.org/10.7251/EMC1801108L.

Levkina, R., Petrenko, A. (2019). Management of innovative marketing techniques as an effective business tool // Agricultural and Resource Economics - International Scientific e-Journal. Vol. 9. No. 1: 37-47.

Li, T., Liu, J., Zhu, H., Zhang, S. (2018). Business characteristics and efficiency of rural tourism enterprises: an empirical study from China // Asia Pacific Journal of Tourism Research. Vol. 23. No. 6: 549-559. https://doi.org/10.14254/1800-5845/2018.14-4.6.

Ma, L.-H., Hsieh, J.-C., Chiu, Y.-H. (2020). A study of business performance and risk in Taiwan's financial institutions through resampling data envelopment analysis // Applied Economics Letters. Vol. 27. No. 11: 886-891. https://doi.org/10.1080/13504851.2019.1646857. 
Mann, R., Bilyk, A. (2017). Monitoring the factors influencing the efficiency of agricultural enterprises' working capital of Ukraine // Problems and Perspectives in Management. Vol. 15. No. 4: 161-167. http://dx.doi.org/10.21511/ppm.15(4).2017.14.

National Bank of Ukraine (2020). Official exchange rate of hryvnia to foreign currencies (average for the period). - https://bank.gov.ua/files/Exchange_r.xls [2020 10 01].

Ponomarenko, T. V, Prokopenko, O. V., Slatvinskyi, M. A., Biloshkurska, N. V., Biloshkurskyi, M. V., Omelyanenko, V. A. (2019). National investment and innovation security assessment methodology // International Journal of Mechanical Engineering and Technology. Vol. 10. No. 2: 847-857.

Prdic, N., Kuzman, B., Damjanovic, J. (2019). Marketing research in the function of business efficiency // Ekonomika poljoprivreda - Economics of Agriculture. Vol. 9. No. 1: 37-47. - https://doi.org/10.5937/ekoPolj1904039P.

Prokopenko, O. V., Kornatowski, R. (2018). Features of modern strategic market-oriented activity of enterprises // Marketing and Management of Innovations. No. 1: 295-303. - https://doi.org/10.21272/mmi.2018.1-22.

Rahmatullin, N. V., Guzelbaeva, G. T. (2019). Digital audit as a factor of business efficiency // International Transaction Journal of Engineering Management \& Applied Sciences \& Technologies. Vol. 10. No. 18. https://doi.org/10.14456/ITJEMAST.2019.250.

Sokil, O., Zhuk, V., Laszlo, V. (2018). Integral assessment of the sustainable development of agriculture in Ukraine // Economic Annals - XXI. Vol. 170. No. 3-4: 15-21. - https://doi.org/10.21003/ea.V170-03.

State Statistics Service of Ukraine (2020). Economic statistics. Economic activity. Activity of enterprises. http://www.ukrstat.gov.ua/operativ/menu/menu_u/sze_20.htm [2020 10 01].

Tambunan, T. (2019). Recent evidence of the development of micro, small and medium enterprises in Indonesia // Journal of Global Entrepreneurship Research. Vol. 9. No. 1. - https://doi.org/10.1186/s40497-018-0140-4.

Vallisova, L., Cerna, M., Hinke, J. (2018). Implementation of sustainability aspects in the financial reporting system: an environmental accounting standard // Economic Annals - XXI. Vol. 173. No. 9-10: 55-59. https://doi.org/10.21003/ea.V173-09. 